University of Nebraska - Lincoln

DigitalCommons@University of Nebraska - Lincoln

$5-1-2005$

\title{
Are Political Orientations Genetically Transmitted?
}

John R. Alford

Rice University

Carolyn L. Funk

Virginia Commonwealth University

John R. Hibbing

University of Nebraska-Lincoln, jhibbing1@unl.edu

Follow this and additional works at: https://digitalcommons.unl.edu/poliscifacpub

Part of the Political Science Commons

Alford, John R.; Funk, Carolyn L.; and Hibbing, John R., "Are Political Orientations Genetically Transmitted?" (2005). Faculty Publications: Political Science. 7.

https://digitalcommons.unl.edu/poliscifacpub/7

This Article is brought to you for free and open access by the Political Science, Department of at DigitalCommons@University of Nebraska - Lincoln. It has been accepted for inclusion in Faculty Publications: Political Science by an authorized administrator of DigitalCommons@University of Nebraska - Lincoln. 


\title{
Are Political Orientations Genetically Transmitted? JOHN R. ALFORD Rice University CAROLYN L. FUNK Virginia Commonwealth University JOHN R. HIBBING University of Nebraska
}

\begin{abstract}
$W$ e test the possibility that political attitudes and behaviors are the result of both environmental and genetic factors. Employing standard methodological approaches in behavioral genetics-specifically, comparisons of the differential correlations of the attitudes of monozygotic twins and dizygotic twins - we analyze data drawn from a large sample of twins in the United States, supplemented with findings from twins in Australia. The results indicate that genetics plays an important role in shaping political attitudes and ideologies but a more modest role in forming party identification; as such, they call for finer distinctions in theorizing about the sources of political attitudes. We conclude by urging political scientists to incorporate genetic influences, specifically interactions between genetic heritability and social environment, into models of political attitude formation.
\end{abstract}

W hy do people think and act politically in the manner they do? Despite the foundational nature of this question, answers are unfortunately incomplete and unnecessarily tentative, largely because political scientists do not take seriously the possibility of nonenvironmental influences. The suggestion that people could be born with political predispositions strikes many as far-fetched, odd, even perverse. However, researchers in other disciplinesnotably behavioral genetics-have uncovered a substantial heritable component for many social attitudes and behaviors and it seems unlikely that political attitudes and behaviors are completely immune from such forces. In this article, we combine relevant findings in behavioral genetics with our own analysis of data on a large sample of twins to test the hypothesis that, contrary to the assumptions embedded in political science research, political attitudes have genetic as well as environmental causes. ${ }^{1}$

Testing this hypothesis is important for two reasons. First and most broadly, as behavioral scientists we need to analyze all possible shapers of behavior, not just a select few. Second, a more complete understanding of the sources of attitudes and behaviors will help us to sort through existing puzzles of considerable interest to political scientists. One example is political ideology. Why is a reasonably standard left-right spectrum so widely applicable cross-culturally and over time? The universal left-right elements of belief systems around

John R. Alford is Associate Professor, Department of Political Science, Rice University, Houston, TX 77251 (jra@rice.edu).

Carolyn L. Funk is Associate Professor, L. Douglas Wilder School of Government and Public Affairs, Virginia Commonwealth University, Richmond, VA 23298 (clfunk@vcu.edu).

John R. Hibbing is Foundation Regents Professor, Department of Political Science, University of Nebraska-Lincoln, Lincoln, NE 68588 (jhibbing@unl.edu).

The authors gratefully acknowledge the assistance of Professor Lindon Eaves and colleagues, particularly for granting us access to data from the sample of twins known as Virginia 30K. Any errors in the analysis or interpretation of the data are, of course, solely our own responsibility.

${ }^{1}$ Evidence consistent with an evolutionary theory of political behavior is found in Brewer 2000, Hibbing and Alford 2004, and Orbell et al. 2004. the world and over the decades is difficult for behavioralists to explain. But if there is a genetic component to political ideologies, if the constraints on belief systems come not just from intellectualization or indoctrination but from something deeper, the concept of ideology takes on greater meaning and the commonality of ideology becomes easier to understand.

\section{ATTITUDE FORMATION}

Debates concerning the source of political attitudes revolve primarily around the question of whether early childhood factors have lasting relevance or whether these factors tend to be overwhelmed by more proximate events. Survey responses to political items presumably reflect attitudes and are thought to be a combination of longstanding "predispositions" and more recent "off-the-top-of-the-head" considerations (Zaller 1992, chaps 1-3; also see Converse 1964). Alternatively, an "on-line" pattern of processing could allow new incidents to ratchet affect one way or another from previously existing summary locations (see Lodge, McGraw, and Stroh 1989). Regardless, proximate forces include recent conversations and experiences, question-wording, priming from previous questions, and a variety of similar factors. Predispositions, on the other hand, are thought to be a "distillation of a person's lifetime experiences, including childhood socialization and direct involvement with the raw ingredients of policy issues" (Zaller 1992, 23). ${ }^{2}$ Great interest exists in determining the relative clout of the early as opposed to the late environment but no interest has been displayed in determining the relative clout of environmental as opposed to genetic variables.

A parallel conclusion applies to research on individual attitudes rather than survey responses generally. For example, the consensus among those who study tolerance is that the extent to which individuals are tolerant hinges on a combination of "antecedent conditions and contemporary information" (Marcus et al. 1995). Antecedent conditions, in turn, are believed to

\footnotetext{
2 To his credit, Zaller (1992) goes on to acknowledge a possible role for "inherited" traits in shaping predispositions (23).
} 
be shaped by "personal circumstances" such as "family, neighborhood, region ... and early group experiences" (Marcus et al. 1995, 5; for more on the importance of long established proclivities, or antecedent conditions, see Stouffer 1955). Typically, no role for geneticallyinduced tendencies is considered (for an exception, see Monroe 2004, chap 6).

More broadly, the literature on political socialization has long revolved around the question of the effects of early as opposed to late environmental forces. Early political socialization researchers (e.g., Easton and Dennis 1969, Greenstein 1960, Jennings and Niemi 1968, and Searing, Schwartz, and Lind 1973) and the authors of The American Voter (Campbell et al. 1960) presented arguments and evidence supporting the primacy of early events. Later researchers, however, questioned the value of early childhood socialization and provided evidence that judgments about more recent conditions and occurrences can dramatically alter preferences we might have held as children and adolescents (see, e.g., Fiorina 1980; for good summaries of the debate over the relative importance of early and late environmental events, see Cook 1985; Merelman 1986, and Sears 1989). In the last 50-60 years, the emphasis in the literature has gone from personality studies (Adorno et al. 1950; Eysenck 1954; Laswell 1930), to ideological and childhood socialization studies, to the effects of media frames, perceptions of current conditions, and other types of contemporary information. In fact, for the past couple of decades research on political socialization has been suffering through a "bear market" (Cook 1985), and studies of personality, while experiencing a remarkable comeback in psychology (for an introduction, see Wiggins and Trapnell 1997), have been largely absent from political science since McCloskey's (1958) work in the 1950s on the conservative personality. Thus, political science debates concerning the source of political attitudes and behaviors have been over timing, over whether attitudes and behaviors are primarily shaped early in life or by more proximate occurrences. Conspicuously absent is consideration of the possibility that certain attitudes and behaviors may be at least partially attributable to genetic factors.

\section{MODERN BEHAVIORAL GENETICS}

But what is the physical process by which a genetic allele could shape a political attitude? If there is any connection at all, is it not that the effect is so small that it can be safely ignored? And even if this is not the case, in light of potentially troubling normative implications such as biological determinism, is it not best to ignore relationships between genes and social behavior? It is difficult for many outside the biological sciences to understand how it is even possible for genes to influence behavior, so a brief discussion is in order. Genes provide instructions for the production of proteins, which are built and identified by a specific combination of amino acids (which in turn are constructed from complex organic molecules). As such, each pro- tein has a chemical sequence that then interacts with other chemicals in the body, sometimes reacting directly with these other chemicals but often serving as enzymes that facilitate but are not themselves altered by chemical reactions. If a gene coding for a particular enzyme is absent, the chemical reaction it is meant to enhance will occur with much less efficiency. For example, a gene for the enzyme tryptophan hydroxylase-2 (Tph2) facilitates production of the neurotransmitter serotonin in the brain, but a certain form of this gene (which varies from the standard form by a single amino acid) produces about $80 \%$ less serotonin and people with this mutant allele appear to be significantly more likely to suffer from unipolar depression (Zhang et al. 2005).

Still, the connection is rarely so simple that a given genetic allele can be seen as causing a certain behavior. More typically, findings in modern behavioral genetics reveal the effect of genes to be interactive rather than direct, let alone determinative. To provide one illustration, in humans there is a gene on chromosome 17 involved with serotonin reuptake (5-HTT). As is often the case with genes, 5-HTT has a long allele and a short allele. Mice have a parallel gene, and in that species the short form had previously been connected to listless, depressive behavior. Scientists were eager to determine if such a correlation between the short form of 5-HTT and depression was present in humans. In a long-term study of the health records of nearly 1,000 New Zealanders whose 5-HTT alleles were known, it was found that major episodes of depressive behavior were not much more prevalent among those with the short form. But then the researchers combined genetics and the environment; specifically, they interacted each subject's 5-HTT allele with the number of high-stress events (romantic calamities, bankruptcies, deaths of loved ones, etc.) experienced in that individual's life. They found that those who had a high number of such events and who had the short form of 5-HTT were significantly more likely to display behaviors associated with depression compared to either those experiencing few high stress events or those with the long form who suffered through a comparably large number of highstress events (see Caspi et al. 2003).

In this particular case, genotype did not make people behave a certain way; rather, it influenced the extent to which their behavior was contingent on the environment-and this pattern likely will apply to all sorts of other human activities. Whether the behavior of interest is depression, cooperation, fear response, or susceptibility to drug addiction, some people are more sensitive than others to particular features of their environment, and genetics, far from determining behavior, influences its sensitivity. Genetics makes the mood of some people far more dependent on the extent to which their lives have been beset with difficulties and it likely makes some people's political attitudes far more contextually dependent than others. In other words, the connection between genes and attitudes may not involve specific attitudes as much as the flexibility of those attitudes (Is abortion always wrong, or does it depend?). The issue is not nature versus nurture but 
the manner in which nature interacts with nurture (see Marcus 2004 and Ridley 2003).

\section{MONOZYGOTIC AND DIZYGOTIC TWINS}

The process of identifying in the laboratory the precise genes responsible for given human behaviors (especially those behaviors that do not have corollaries in lab-friendly animals such as mice) is extremely challenging. Fortunately, even without identifying the genes responsible, it is possible to compile information on the matter of most concern to social scientists: the extent to which attitudes and behaviors have a genetic component. The relevant procedures center on comparisons of monozygotic (MZ; frequently but erroneously called identical) twins and dizygotic (DZ; fraternal) twins.

MZ twins develop from a single egg, fertilized by a single sperm, and share an identical genetic inheritance. DZ twins develop from two separate eggs, fertilized by two separate sperm, and are in effect simply two siblings that happen to be born simultaneously. As such, DZ twins share the same average of $50 \%$ of genetic material as do any two biological siblings. It is this fixed ratio (two to one) of genetic similarity between $\mathrm{MZ}$ and DZ twins, and the contrasting average equivalence of environment influence, that provides most of the power of twin designs. It is important to appreciate that the assumption of environmental equivalence is one of equivalence across types of twins, not across pairs of twins or across twins within a given pair. For example, there is undoubtedly at least some variability in parental socialization across siblings, even those of identical age, but across multiple twin pairs the assumption is that this variability is essentially equal for the $\mathrm{MZ}$ and the DZ pairs.

This assertion that the effect of genetics is measurably distinct for $\mathrm{MZ}$ and $\mathrm{DZ}$ twins, while the effect of the environment is either equivalent or at least randomly distributed around equivalence, is crucial to everything that follows from twin research. It is important therefore to raise and consider the criticisms of this fundamental assumption. The arguments come in two essential varieties. The first is that MZ twins, genetics aside, experience a more similar environment because they are treated more similarly than are DZ twins. This would seem particularly telling for childhood socialization, where, for example, parents might show less of a tendency to treat $M Z$ twins as individuals compared to $\mathrm{DZ}$ twins. The second is that MZ twins, genetics aside, interact with each other more throughout life than do DZ twins. This would seem to be of particular importance for adult socialization, where closer adult contact between MZ twins might lead us to expect a greater degree of environmentally induced similarity than we would see for the more distant DZ twins.

Both caveats have been subject to sustained and varied investigation and neither has been found to hold up under empirical scrutiny. The argument of more similar treatment fails on several fronts. Parents frequently miscategorize their twins (DZ twins are often believed by their parents to be $\mathrm{MZ}$ twins) and the differential correlation persists in these instances of miscategorization. In other words, the degree of correspondence between MZ twins surpasses that of DZ twins even in the large subpopulation of twins thought by their parents to be MZ twins (Bouchard and McGue 2003; Bouchard et al. 1990; Plomin 1990). The contention that MZ twins have closer or more frequent contact than DZ twins turns out to be at best irrelevant. The correlation between the frequency of contact between twins and the similarity between twins on all attitudinal and behavioral variables tested, including conservatism, is slight and actually negative (Martin et al. 1986). In other words, twins in greater contact with their cotwins are not more likely to share the same attitudes and behaviors, so even if MZ twins have more contact than DZ twins, this contact is not the cause of any elevated correlations. But the most powerful refutation of both of these criticisms comes in recent studies utilizing MZ and DZ twins raised apart. These studies uniformly validate $\mathrm{MZ}$ and $\mathrm{DZ}$ differences found in earlier studies of twins raised together. Arguments about the relative degree of shared environmental effects between MZ and DZ twins simply offer no credible explanation if the twins in question have been raised apart (Bouchard 1998; Bouchard et al. 1990). In effect, this naturally occurring, if uncommon, condition provides precisely the sort of laboratory control that we would want in an experimental setting. ${ }^{3}$

Other evidence against the exclusive environmental argument is that the empirical results suggest MZ twins reared together are often less likely to share behavioral traits with their twins than are MZ twins reared apart, presumably because of extra efforts to establish distinct identities when the twins live together. In addition, as adult MZ twins living apart age, they tend to become more, not less, similar (Bouchard and McGue 2003), a finding that is difficult to reconcile with the belief that only the environment matters. Interestingly, this precise effect is predicted in an early landmark criticism of behaviorism and the conditioned response research on animal behavior that formed its empirical core. Over time, substantial anomalies began to accumulate in this research pointing toward a primacy for some nonenvironmental behaviors. Breland and Breland (1961) summarized this tendency with the phrase "learned behavior drifts toward instinctive behavior" (684).

Given the genetic differences and environmental similarities of the two types of twins, for any trait that is partly heritable the tendency for MZ twins to share that characteristic should be stronger than the tendency for DZ twins to share that characteristic. In contrast, characteristics that arise purely from the environment, whether shared by the twins, as would typically be the case for parental socialization, or not

\footnotetext{
3 To explain this finding, opponents would need to argue that adoption agencies are more likely to place MZ twins in similar homes than they are to place DZ twins in similar homes. In fact, information on twin zygosity is typically unavailable to those making placement decisions, and even if it were available, it seems highly unlikely that it would factor into their decisions.
} 
shared by the twins, as would be the case for many adult experiences, should not generate any significantly different patterns when we contrast MZ and DZ twins (see Eaves, Eysenck, and Martin 1989 and Plomin et al. 2001 for a thorough discussion of the relevant statistical techniques).

The procedures involved with the twin methodology are standard fare in behavioral genetics but are not familiar to most political scientists, so it is appropriate that we explain the basic terminology, theory, and technique in some detail. Influences on an individual trait, whether it is a political attitude or a physical characteristic, are typically divided into two broad groups-heredity $(\mathrm{H})$ and environment $(\mathrm{E})$. The total variation in a trait can thus be represented as the sum $\mathrm{H}+\mathrm{E}$. Heredity is the impact of genetic inheritance on trait variation. In the case of a physical characteristic such as adult height, this would be the proportion of the total variation in height across individuals due to the variation across individuals in the multiple genes that control ultimate physical height. For any one individual, the source of this genetic influence is relatively well defined, as on average $50 \%$ of our genes come from our mother and $50 \%$ come from our father. This leads to the fact that biological children of tall parents are more likely to be tall than are the biological children of short parents, though even for a relatively straightforward additive physical trait like height, the relationship is far from determinative.

"Environment" is all of the nongenetic external factors that influence trait variation across a population. These influences range broadly from the earliest biological environment of the womb, to the physical environment of a childhood house, to the social environment of the adult workplace. In the case of adult height, some of the obvious environmental factors are prenatal nutrition, the adequacy of childhood and adolescent diet, and exposure to chemical agents that can inhibit growth.

Environmental influences can be further divided into two subcategories: the shared environment and the unshared, or unique, environment. The shared environment is all of the shared external influences that we would typically think of as leading to trait similarity between individuals. Siblings, for example, might share similar childhood environments, including similar parental interactions, a similar physical environment, and similar nutrition. If the siblings happen to be twins, they would also share a more similar prenatal environment. ${ }^{4}$ In the case of adult height, a shared environmental factor, such as a regional diet limited in protein and specific nutrients, could lead to similarity in height across the entire population of a region.

The unshared environment is all of the distinctive external influences that we would typically think of as

\footnotetext{
${ }^{4}$ However, recent research suggests that the prenatal environment is so important that it can cause variation even in fetuses inhabiting the uterus at the same time. Prescott, Johnson, and McArdle (1999) present evidence that MZ twins sharing the same chorion, the outermost extraembryonic membrane, are more similar in terms of personality and cognitive abilities that MZ twins in separate chorions.
}

leading to trait dissimilarity across individuals. While much of the early childhood environment, for example, is similar across siblings, much is nonetheless variable. Siblings differ in diet, disease exposure, peer influences, and a host of other unique experiences. Even twins, whose childhood environment is made increasingly similar by virtue of their identical age, are exposed to substantial unique external influences. With the shift to adult life, the share of unique influences on siblings increases sharply, as peer, workplace, family, and physical settings typically diverge.

In the classic political science studies of socialization (see, especially, Jennings and Niemi 1968, 1991 and Tedin 1974), the focus has been on the correlation between the attitudes of parents and their children. In terms of the three sources of trait variability outlined above, as informative as it is, this design does not allow for an unambiguous estimation of any of the three categories. The correlation between a parent and a child arises from a combination of shared genes, shared environment, and parental socialization (an indirect form of shared environment in which the parent's attitudes provide a path from the parent's environment to the child's environment), all of which are pressures toward similarity in parent-child attitudes. The failure of this parent-child correspondence to reach +1.0 presumably reflects the pressure toward dissimilarity coming from the unshared environment, but since the genetic similarity of a parent-offspring pair is only .5 , there is as much genetic dissimilarity as there is similarity. Thus, trait dissimilarity, like trait similarity, is an undetermined mixture of genetic and environmental influences. Our inability to tease apart genetic heritability and environment, whether shared or unshared, in these parent-child studies is a direct result of the fact that there is no measured variation in genetic similarity across the data set of parent-child pairs (i.e., all biological offspring share the same average of $50 \%$ of the variable genetic code with each parent).

This inability of standard parent-child observations to distinguish genetic heritability from parental socialization (or other features of the shared environment) is something that has long been understood, but largely ignored in modern social science. Fortunately, twins provide a powerful "natural experiment" by introducing known genetic variation into analyses of the sources of trait variability. By shifting the focus from the similarity between parents and offspring to the similarity between two siblings, we can take advantage of the fact that some siblings vary in well-known ways in the degree of their genetic correlation.

\section{POLITICS AND GENETICS: PREVIOUS FINDINGS AND OUR EXPECTATIONS}

Comparisons of the correlations of MZ and DZ twins on a wide variety of variables have been conducted, with intriguing results. Using appropriate modeling techniques including controls for parental traits and assortative mating, it is possible to partition the explanatory powers of heredity, shared environment, and 
nonshared environment on any given variable. These techniques have been valuable for epidemiological traits, intelligence, personality, social attitudes such as those connected to religion, psychological interests, and behaviors such as risk-taking propensities (for a thorough review, see Bouchard and McGue 2003). Of most interest to us are the findings pertaining to social attitudes and behaviors. At first, researchers were so confident that social attitudes were not heritable that they employed such items as controls. Quickly they discovered that other controls would have to be found because most social attitudes consistently displayed a surprising measure of heritability (see, e.g., Crelia and Tesser 1996, Scarr and Weinberg 1981, and Tesser 1993).

Political attitudes were never a central focus in this research stream but many of the patterns found in other social attitudes should be present for political attitudes as well, and this assumption guided the formulation of our expectations. Since the social attitudes tested to date have demonstrated a strong heritable component, frequently stronger than attitude covariance attributable to shared environment, we predict that political attitudes will also be heavily heritable. Heritability estimates calculated by previous researchers for attitudes associated with psychological conservatism are quite high, while the relevant models typically show little or no effect for shared environment (the remainder is likely the result of nonshared environmental factors). Notably, these findings come from studies of twins in settings as disparate as Australia, Virginia, and Minnesota, and the findings of the Minnesota study, utilizing twins reared apart, conform well to the other studies of twins raised together (for a summary, see Bouchard and McGue 2003). ${ }^{5}$ Careful studies of adopted children confirm the finding that genetics matter more than parentally created environment in influencing social attitudes and behaviors, personality traits, and intelligence. ${ }^{6}$

We further predict that attitudes on political issues tracking most closely to central personality traits should be the most heritable since personality traits are generally heritable and since the heritability of social attitudes is likely derivative of the heritability of various personality traits (see Bouchard and Loehlin

\footnotetext{
5 Conservatism is not unusual in this regard. Rushton, Littlefield, and Lumsden $(1986,7340)$ find that approximately $50 \%$ of the variance in altruism is the result of "direct genetic inheritance," with family environment responsible for $0 \%$.

${ }^{6}$ Adoption studies measure the correlation of biological parents and adopted children where the biological parents have had no contribution to the rearing (environment) of the child. The most recent adoption study, utilizing surveys of Korean-American adoptees randomly assigned to families in the United States, concludes that roughly $75 \%$ of variance in children's educational attainment is attributable to the educational attainment of their biological parents, and only $25 \%$ is attributable to the adoptive parents, thus dramatically confirming the earlier findings of a substantial correlation between biological parents and adopted children and a surprisingly paltry correlation between adoptive parents and children (Sacerdote 2004). This parallels, with an entirely distinct methodology, the basic finding of the twin studies (see Plomin et al. 1997, 1998 and Rhee and Waldman 2002).
}

2001 and Eaves, Eysenck, and Martin 1989). For example, one of psychology's "Big 5" personality traits is general "openness" and it seems likely degree of openness is relevant to the political arena as well. Liberals and conservatives, on average, differ in their openness to atheism, homosexuality, communism, immigration, and countercultural activities. These differences may be entirely due to enculturation, but then again, they may not be, and we will never know without testing for the effects of genetics.

Based on behavioral geneticists' study of religion, it seems that group identification is something that is heavily influenced by the environment, especially shared environment, and is mostly unconnected to genetics. Children of Methodists are likely to be Methodists not because there is a gene for Methodism or even a personality particularly oriented toward Methodism, but because of parental socialization. Thus, even as attitudes connected to religiosity and religious beliefs and activities (e.g., Sabbath observance, church authority, belief in heaven, religious fundamentalism, frequency of attendance) were found to be shaped more by genetic inheritance than by parental views on those issues (for details, see Bouchard et al. 1999, Eaves, Martin, and Heath 1990, Maes et al. 1999, and Martin et al. 1999), identification with a particular religious group was shaped more by socialization and almost not at all by genetics. We expect to find a similar pattern with political party identification. Children are eager to belong to the groups their parents belong to and parents are frequently eager to encourage children in this regard. Assuming these identifications have some stickiness into early adulthood, our core expectation is that party identification will be influenced more by parental socialization (shared environment) than by genetic inheritance but that this pattern will be reversed for political attitudes with inheritance playing a role at least as large as the shared environment. By predicting a large influence for genetic inheritance, we depart from typical behavioralist expectations anticipating that political attitudes will be predominantly influenced by environmental factors, rendering genetic inheritance largely, if not completely, inconsequential.

\section{DATA AND METHODS}

Since twin studies have not been conducted by political scientists, political attitudes have been at best a sidelight, and properly refined measures of political variables have not been constructed and employed (the heritability of political behavior has not been analyzed at all). Nonetheless, some previously employed variables in twin studies have political relevance. For example, the heritability of conservatism is frequently assessed (see, e.g., Bouchard et al. 1990, Eaves, Eysenck, and Martin, 1989, and Martin et al. 1986), and even though conservatism is viewed by the scholars who do twin studies more as a psychological trait than a political ideology, measures of it include political items.

Of most relevance here is the Wilson-Patterson (W-P) Attitude Inventory. This inventory is administered by presenting subjects with a short stimulus 
phrase such as death penalty or royalty and eliciting a simple agree, disagree, or uncertain response. The broadest version of the $\mathrm{W}-\mathrm{P}$ inventory includes 50 items, 25 of which contribute positively to the conservatism score and 25 of which contribute negatively to the conservatism score. While some of the items relate to a heavily social conception of conservatism-for example, pajama parties, nudist camps, computer music, and horoscopes-others have a much more direct political content-for example, disarmament, socialism, patriotism, and death penalty. Studies typically utilize reduced sets of W-P items or modify individual items to better suit the country in which the items are being administered. For political science this presents two frustrations. The list of politically relevant items is tantalizing but limited and unfocused, and the results are often presented only for the entire combined scale, making it difficult to assess the contribution of the directly political items to the overall index of heritability.

We were granted access to the data for the W-P items in the United States and were able to conduct comparable, though more limited, twin correlation analyses from published results of an Australian study. ${ }^{7}$ The U.S. study included information on thousands of twin pairs in Virginia, supplemented with twin pairs recruited through the cooperation of AARP. A subset of these twins and their relatives has been asked questions regarding their social attitudes, including numerous items from the $\mathrm{W}-\mathrm{P}$ inventory.

A brief explication of twin methodology should help readers make independent sense of the tables. The standard techniques in behavioral genetics are based on correlation analysis (in the case of limited response items like the W-P inventory, the actual measure is the polychoric correlation coefficient, a technique that is appropriate when individual subjects are using a limited set of categories to express location on what is in

\footnotetext{
${ }^{7}$ Our thanks go to Professor Lindon Eaves at Virginia Commonwealth University for making the VA30K data available to us. The data collection methods for both studies are summarized in Lake et al. 2000 as follows: "The Australian sample was ascertained through two cohorts of twins. The first cohort was recruited in 19801982 from a sampling frame which comprised 5967 twin pairs aged 18 years or older (born 1893 to 1964) then enrolled on the Australian NHMRC Twin Registry (ATR). Responses were obtained from 3808 complete pairs ... and these were followed up with a second mailed questionnaire in 1988-1990 with responses from 2708 complete pairs. ... The second cohort of twins, born 1964-1971, was recruited from the ATR in 1989 and was mailed similar questionnaires in 1989-1991, with responses from 3,769 individuals of 4269 eligible pairs... In total there were 21,222 respondents in the Australian sample, of whom 20,945 had valid scores for EPQ Neuroticism. The United States twins were ascertained from a populationbased birth registry for the Commonwealth of Virginia and from a volunteer sample through the American Association of Retired Persons (AARP), described in detail by Truett et al. (1994). Their first-degree relatives and spouses were recruited in a similar fashion to the Australian sample, and in total there were 24,905 respondents (of 29,080) with valid scores for Neuroticism and for whom the zygosity of the proband twins could be determined. The response rates were $70 \%$ for twins and $45 \%$ for relatives" $(224-25)$. The original U.S. twin data collection was funded in part by NIH grants GM30250 and AG04954, by ADAMHA grants AA06781, AA07728, AA07535, and MH40828, and by a gift from R. J. R. Nabisco.
}

fact a continuous trait). The correlations are computed separately for male/male and female/female twin pairs to provide an appropriate comparison, since all MZ twins are same-sex pairs, while DZ twins are a mix of same-sex and opposite-sex pairs (in other words, female/male DZ twin pairs are excluded from the analysis). Without this control, the presence of any male/ female differences would spuriously deflate the correlations for $\mathrm{DZ}$ pairs relative to the same-sex $\mathrm{MZ}$ pairs.

Heritability is typically estimated by subtracting the correlation for DZ pairs from the correlation for MZ pairs and then doubling the resulting difference. At one extreme, if the correlations are the same for MZ and DZ pairs, suggesting that genetic similarity plays no role in similarity for that particular trait, then the result will be an estimate of heritability of zero. At the other extreme, a purely genetic additive trait should produce a correlation of .5 for DZ pairs and 1.0 for MZ pairs, resulting in an estimate of heritability of $1.0(1.0-.5=.5$, and $2 * .5=1.0)$. In a similar way, we can estimate the influence of shared environment, as opposed to shared genetic material, by doubling the correlation for DZ pairs and then subtracting the correlation for MZ pairs. Again, a purely genetic additive trait should produce a correlation of .5 for $\mathrm{DZ}$ pairs and 1.0 for $\mathrm{MZ}$ pairs, resulting in an estimate of the impact of shared environment of zero $(2 * .5=1.0$, and $1.0-1.0=0)$. At the other extreme, if the correlations are the same for MZ and DZ pairs, suggesting that genetic similarity plays no role in similarity for that particular trait, then the result will be an estimate of the impact of shared environment that is equal to the $\mathrm{MZ}$ or $\mathrm{DZ}$ correlation (e.g., if $\mathrm{MZ}=\mathrm{DZ}=.4$, then $2 * .4=.8$, and $.8-.4=.4$ ). Whatever is left over is taken to be attributable to the unshared environment.

\section{THE HERITABILITY OF POLITICAL ATTITUDES}

Table 1 contains the results of a standard polychoric correlation analysis for the $28 \mathrm{~W}-\mathrm{P}$ items available in the Virginia $30 \mathrm{~K}$ data set and for a select set of additional items to provide some sense of perspective for the level of these correlations. Even the quickest glance at the results in Table 1 is enough to set aside the traditional view that genes do not play any role in explaining political attitudes. All 28 of the MZ correlations are larger than their corresponding DZ correlations, and in every case the difference is statistically significant at the .01 level. Far from typically being at or near zero, none of the 28 heritability estimates falls in the single digit range, and more than half of the 28 items have heritability estimates of .3 or more. Heritability ranges from a high of .41 to a low of .18, all suggesting that the influence of heredity on political attitudes is very real, and given the diverse range of items included here, this genetic influence is also pervasive. So the view that heritability of social and political attitudes will be nonzero but small relative to shared environment is also called into question. We see from Table 1 that the 


\begin{tabular}{|c|c|c|c|c|c|c|c|c|}
\hline \multirow[b]{3}{*}{ Attitude Item } & \multicolumn{4}{|c|}{ Polychoric Correlation } & \multirow{3}{*}{$\begin{array}{c}\text { Heritability, } \\
2 *(M Z-D Z)\end{array}$} & \multirow{3}{*}{$\begin{array}{l}\text { Shared } \\
\text { Environment, } \\
(2 * D Z)-M Z\end{array}$} & \multirow{3}{*}{$\begin{array}{c}\text { Unshared } \\
\text { Environment, } \\
1-M Z\end{array}$} & \multirow{3}{*}{$\begin{array}{l}z \text { for }(M Z-D Z) \\
\text { Difference }\end{array}$} \\
\hline & \multicolumn{2}{|c|}{$\mathrm{MZ}$} & \multicolumn{2}{|c|}{ DZ } & & & & \\
\hline & Corr. & $n$ & Corr. & $n$ & & & & \\
\hline School Prayer & 0.66 & 2,687 & 0.46 & 1,774 & 0.41 & 0.25 & 0.34 & 9.83 \\
\hline Property Tax & 0.47 & 2,643 & 0.27 & 1,748 & 0.41 & 0.06 & 0.53 & 7.66 \\
\hline Moral Majority & 0.42 & 2,614 & 0.22 & 1,717 & 0.40 & 0.03 & 0.58 & 7.16 \\
\hline Capitalism & 0.53 & 2,609 & 0.34 & 1,720 & 0.39 & 0.14 & 0.47 & 7.85 \\
\hline Astrology & 0.48 & 2,631 & 0.28 & 1,721 & 0.39 & 0.09 & 0.52 & 7.39 \\
\hline The Draft & 0.41 & 2,641 & 0.21 & 1,753 & 0.38 & 0.02 & 0.59 & 6.94 \\
\hline Pacifism & 0.34 & 2,576 & 0.15 & 1,686 & 0.38 & -0.04 & 0.66 & 6.43 \\
\hline Unions & 0.44 & 2,661 & 0.26 & 1,752 & 0.37 & 0.07 & 0.56 & 6.89 \\
\hline Republicans & 0.48 & 2,627 & 0.30 & 1,734 & 0.36 & 0.12 & 0.52 & 6.91 \\
\hline Socialism & 0.43 & 2,616 & 0.25 & 1,726 & 0.36 & 0.07 & 0.57 & 6.53 \\
\hline Foreign Aid & 0.41 & 2,669 & 0.23 & 1,771 & 0.35 & 0.06 & 0.59 & 6.42 \\
\hline X-Rated Movies & 0.63 & 2,685 & 0.46 & 1,783 & 0.35 & 0.28 & 0.37 & 8.15 \\
\hline Immigration & 0.45 & 2,658 & 0.29 & 1,748 & 0.33 & 0.12 & 0.55 & 6.20 \\
\hline Women's Liberation & 0.46 & 2,666 & 0.30 & 1,779 & 0.33 & 0.13 & 0.54 & 6.27 \\
\hline Death Penalty & 0.56 & 2,684 & 0.40 & 1,775 & 0.32 & 0.24 & 0.44 & 6.83 \\
\hline Censorship & 0.40 & 2,629 & 0.25 & 1,718 & 0.30 & 0.10 & 0.60 & 5.36 \\
\hline Living Together & 0.67 & 2,679 & 0.52 & 1,771 & 0.30 & 0.37 & 0.33 & 7.54 \\
\hline Military Drill & 0.38 & 2,625 & 0.24 & 1,733 & 0.29 & 0.09 & 0.62 & 5.24 \\
\hline Gay Rights & 0.60 & 2,658 & 0.46 & 1,767 & 0.28 & 0.32 & 0.40 & 6.26 \\
\hline Segregation & 0.38 & 2,653 & 0.24 & 1,743 & 0.27 & 0.11 & 0.62 & 4.83 \\
\hline Busing & 0.43 & 2,670 & 0.30 & 1,766 & 0.26 & 0.16 & 0.57 & 4.92 \\
\hline Nuclear Power & 0.42 & 2,646 & 0.29 & 1,744 & 0.26 & 0.16 & 0.58 & 4.84 \\
\hline Democrats & 0.47 & 2,639 & 0.34 & 1,726 & 0.26 & 0.21 & 0.53 & 4.96 \\
\hline Divorce & 0.47 & 2,659 & 0.34 & 1,765 & 0.26 & 0.21 & 0.53 & 4.99 \\
\hline Abortion & 0.64 & 2,668 & 0.52 & 1,768 & 0.25 & 0.39 & 0.36 & 6.23 \\
\hline Modern Art & 0.43 & 2,662 & 0.30 & 1,765 & 0.25 & 0.18 & 0.57 & 4.69 \\
\hline Federal Housing & 0.36 & 2,665 & 0.26 & 1,766 & 0.20 & 0.16 & 0.64 & 3.61 \\
\hline Liberals & 0.44 & 2,629 & 0.35 & 1,734 & 0.18 & 0.26 & 0.56 & 3.40 \\
\hline 28-item mean & 0.47 & 2,648 & 0.31 & 1,748 & 0.32 & 0.16 & 0.53 & \\
\hline
\end{tabular}

Source: Access to the data provided by Eaves et al., principal investigators, Virginia 30K twin study (see note 7)

${ }^{a}$ The MZ-DZ correlation difference is statistically significant for all of the table items at the 0.01 level or above.

impact of shared environment exceeds that of heredity for only four of the 28 items, and the mean estimate of heritability for the $28 \mathrm{~W}-\mathrm{P}$ items is .32, compared to a mean estimate of shared environmental influence of .16 .

The second-to-last column in Table 1 reports the estimates for the proportion of the variation in an attitude that is attributable to the unshared environment. As described above this is essentially a residual variance category, reflecting such factors as random choice as well as external influences such as the unique experience of each individual, including those from childhood, and later influences in life that have been termed "adult socialization" in the political science literature. Across the $28 \mathrm{~W}-\mathrm{P}$ items the estimate of the impact of unshared environment varies from about one-third (for School Prayer) up to about two-thirds (for Pacifism) of the overall variation. The average impact of the unshared environment for these items is .53, or roughly half of the overall variation. The summary picture for this set of political attitudes, then, is that shared influences (genetic and environmental) account for about half of the variation in these political reactions, with unique individual and environmental factors account- ing for the remainder. Within the half that is accounted for by shared influences, genetic influences, in contradiction to behavioralist expectations, are roughly twice as influential as environmental influences.

While the individual items provide interesting variation, the purpose of the W-P inventory is to provide an overall index of conservatism. We compute a simple index by assigning a value of +1 to any "conservative" response (i.e., a "yes" to an item like Death Penalty or a "no" to an item like Women's Liberation) and -1 to any "liberal" response (i.e., a "no" to an item like Death Penalty or a "yes" to an item like Women's Liberation). Items where the respondent chose a noncommital (?) response are coded as zero. When these individual scores are summed across the 28 items they yield an index that varies from a potential low of -28 (indicating a set of uniformly "liberal" responses) to a high of +28 (indicating a set of uniformly "conservative" responses). The actual index scores for the twins in the study range from -26 to +26 , with the median response falling between +2 and +3 . Given the far more continuous nature of this overall index, we can now utilize the more traditional Pearson's correlation coefficient. The results for the overall index 
TABLE 2. Genetic and Environmental Influences on Political Attitudes: Summary Index and Additional Non-Wilson-Patterson Items

\begin{tabular}{|c|c|c|c|c|c|c|c|c|}
\hline \multirow[b]{3}{*}{ Attitude Item } & \multicolumn{4}{|c|}{ Correlation } & \multirow{3}{*}{$\begin{array}{l}\text { Heritability, } \\
2 *(\mathrm{MZ}-\mathrm{DZ})\end{array}$} & \multirow{3}{*}{$\begin{array}{c}\text { Shared } \\
\text { Environment, } \\
(2 * D Z)-M Z\end{array}$} & \multirow{3}{*}{$\begin{array}{c}\text { Unshared } \\
\text { Environment, } \\
1-M Z\end{array}$} & \multirow{3}{*}{$\begin{array}{l}z \text { for }(M Z-D Z) \\
\text { Difference }^{a}\end{array}$} \\
\hline & \multicolumn{2}{|c|}{$M Z$} & \multicolumn{2}{|c|}{$\mathrm{DZ}$} & & & & \\
\hline & Corr. & $n$ & Corr. & $n$ & & & & \\
\hline \multicolumn{9}{|l|}{ Pearson's correlation coefficient } \\
\hline 28-item index score & 0.65 & 2,107 & 0.43 & 1,384 & 0.43 & 0.22 & 0.35 & 8.93 \\
\hline $\begin{array}{l}\text { Partial corr. for parent, } \\
\text { same index }\end{array}$ & 0.64 & 173 & 0.37 & 131 & 0.53 & 0.11 & 0.36 & 3.08 \\
\hline Opinionation & 0.39 & 2,107 & 0.20 & 1,384 & 0.36 & 0.02 & 0.61 & 5.77 \\
\hline \multicolumn{9}{|c|}{ Polychoric correlation coefficient } \\
\hline 28-item mean & 0.47 & 2,648 & 0.31 & 1,748 & 0.32 & 0.16 & 0.53 & \\
\hline Educational Attainment & 0.86 & 2,683 & 0.66 & 1,771 & 0.40 & 0.46 & 0.14 & 16.40 \\
\hline Party Affiliation & 0.55 & 2,417 & 0.48 & 1,554 & 0.14 & 0.41 & 0.45 & 2.99 \\
\hline $\begin{array}{l}\text { Mean of affect toward Reps. } \\
\text { and Dems. }\end{array}$ & 0.48 & 2,633 & 0.32 & 1,730 & 0.31 & 0.17 & 0.52 & 5.94 \\
\hline
\end{tabular}

are presented in Table 2 and clearly support a powerful role for heredity in influencing conservatism, at least as measured by the W-P inventory. The estimate for heritability is .43 , higher than for any of the individual items. The estimate for shared environment is .22, falling within the upper range of the individual items, while the estimate for unshared environment is only .35 , falling very near the bottom of the range for individual items. The overall picture is again a very strong role for heredity and a less powerful, but clear role for shared environment. What is different for the overall index is that the role of shared influences (genetic and environmental) account for almost two-thirds of the variation in the index (compared to about one-half for the individual items), with unique individual and environmental factors accounting for only about onethird of the variation. This decline in the role of unique individual and environmental factors seems sensible, as we are moving from individual and highly specific items that could involve a host of unique experiential, associational, and informational perturbations to an index where those idiosyncratic features of individual items have the opportunity to cancel each other out.

The W-P items can also be used to construct a rough index of political opinionation by taking advantage of the frequency of ? responses. The number of times that a respondent chose a yes or no response over a neutral ? response was summed to produce an index that varies from zero to 28 , with a 28 indicating that the respondent was willing to express a directional opinion on all 28 items and a score of zero indicating that the respondent was unwilling to offer a directional opinion on any of the 28 items. The median for this index is 21 yes or no response choices of 28 possible. The results for the overall index clearly support a powerful role for heredity in influencing political opinionation, at least as it is captured by the admitted rough gauge of the frequency of nonneutral responses to the $\mathrm{W}-\mathrm{P}$ inventory items. The estimate for heritability is
.36 and the estimate for shared environment is only .02. The estimate for unshared environment is high, at .61, falling near the top of the range for individual items. To the extent that there is a family effect on political opinionation, it would appear to be entirely a genetic one, with the remaining roughly two-thirds of the variation being due to nonshared factors.

Two items from the survey that are not a part of the W-P inventory are included in Table 2. Party affiliation is the most clearly political of the items in the broader questionnaire, and it is useful here on its own, as well as in contrast to the attitudinal items. Party identification is distinct among U.S. political attitudes both in our conception of it as an identification, and hence as something at least potentially distinct from simple item evaluation, and in its established tendency to correlate well between parent and child (see Jennings and Niemi 1968). This distinctiveness is apparent in Table 2. As we expected, the pattern for party identification is nearly the exact reverse of that for the average attitude item. Heritability for party affiliation is relatively low $(r=.14)$, while shared environment is much stronger $(r=.41)$. Note also that not one of the $28 \mathrm{~W}-\mathrm{P}$ items has an average heritability that is as low as that for party affiliation, and likewise, not one of the 28 items has an average coefficient for the impact of shared environment that is as high as that for party affiliation. Clearly, party identification is, at least for the United States, a different sort of beast than reactions to issue items.

In this regard it is particularly interesting that the two major parties also appear in the W-P battery, but here they are objects of affect rather than labels of possible identification, and the "pro" or "con" reactions to the parties that these items pick up do not exhibit the same patterns of genetic and environmental influence that we see for party affiliation. In fact, if we average the polychoric correlation for the "Democrats" item with the correlations for the "Republicans" item and compute the resulting estimates we get a heritability 
estimate of .31 and a shared environment estimate of .17 , almost exactly the same as the mean results for all 28 attitude items. It would appear that affect toward the major parties is largely a matter of genetic predisposition but that, just as the political socialization literature has concluded all along, party identification itself is primarily the result of parental socialization. This pattern is intriguing in and of itself but it also should give pause to those who would dismiss the findings on attitude items as the product of some methodological quirk of twin studies. If estimates of heritability are somehow artificially inflated, why does this alleged contamination not occur for party identification?

Table 2 also reports the results for a summary indicator of educational attainment from the survey. We include it here partly because it reflects an actual behavior, if only a self-reported one, and partly because it carries the role of genetics more directly into the world of actual and meaningful social variation. Educational attainment is also useful as an example of a behavior that is traditionally thought to be heavily influenced by shared environment, particularly by parental example, expectations, and resources. This traditional view is supported by the shared environment estimate of .46, a figure higher than any of the estimates for the 28 attitude items and even somewhat higher than the estimate for party ID. What may surprise readers is that as important as shared environment is to educational attainment, heredity, at .40, is almost as important. Taken together, family effects are almost the entire story for variation in education attainment. The estimate for the impact of the unshared environment is only .14, a value markedly lower than any other in the table.

\section{ASSORTATIVE MATING}

Assortative mating is a particular concern here. As detailed above, the assumption that DZ twins, like any other pair of biological siblings, share on average $50 \%$ of the variable genetic code is crucial to the estimation of heritability. This contrasts with MZ twins, where the shared proportion is $100 \%$, and the DZ level forms the baseline for separating genetics from the shared environment. What may not be immediately apparent is that the assumption that purely genetic traits in DZ twins will on average correlate at .50 is itself built on the assumption that their biological parents will on average correlate at .00 for the same traits. In other words, the assumption is that the parents are not related to each other in any close degree, and this is typically true, as close relatives generally do not mate, and the amount of average shared genetic code drops geometrically as we move away in relatedness and quickly approaches zero. This assumption that mates are genetically uncorrelated on the trait of interest is, however, violated if mate choice is itself based on the trait of interest. If, for example, parents have identical genetic codes for a trait of interest, then the shuffling of that genetic code produced by sexual reproduction will not result in any variation among DZ twins, or any other siblings, with regard to their genotype for that trait. In other words,
DZ twins of these parents will be as genetically alike on this one trait as MZ twins are on this trait. Across a study population, the higher the proportion of spouses that share identical genetics for a trait, the closer the DZ correlation will be to the MZ correlation. Since heritability of a trait is estimated as $2 *(\mathrm{MZ}-\mathrm{DZ})$, the increased similarity of $\mathrm{DZ}$ and $\mathrm{MZ}$ pairs will lead to an underestimation of heritability for this genetic trait.

This is important for our assessment of the heritability of political attitudes. If there is a tendency for people to choose mates with similar positions on political issues, then the estimates of heritability in Tables 1 and 2 are biased. Fortunately for us, the direction of the bias is uniform and conservative. Any measurable tendency toward assortative mating on political orientation will push up the DZ twin correlation while leaving the MZ correlation unaffected, and this reduction in the MZ-DZ gap will have the related effect of lowering estimates of heritability. Note also that any increase in similarity of DZ twins will inflate the estimate of the importance of shared environment, as the estimation formula of $(2 * \mathrm{DZ})-\mathrm{MZ}$ makes clear.

The immediate empirical question is how much of a role assortative mating plays in political issue positions. A quick answer can be found by looking at the interspouse polychoric correlations for the individuals included in the Virginia $30 \mathrm{~K}$ study. The average interspouse polychoric correlation for the 28 items is .41 and the individual correlations range from a low of .26 for Censorship to a high of .64 for School Prayer. While some of this interspouse similarity could plausibly be attributed to persuasion effects taking place after mate choice rather than to assortative mating, the levels of similarity are probably too high to dismiss assortative mating entirely. This is confirmed by a preliminary look at the impact of controlling for assortative mating on these 28 attitude items. The Virginia $30 \mathrm{~K}$ study includes data for parents of twins in the study, including parents' individual responses to the same W-P items that the twins responded to. The usable sample size does drop substantially when we restrict our analysis to only twin pairs with completed $\mathrm{W}-\mathrm{P}$ results for both parents (there are a total of 304 pairs of male/male or female/female twins with complete twin and parent W-P data, compared to approximately 4,400 pairs in the twin only analysis in Table 1). This effectively limits us to an assortative mating analysis that focuses on the overall index score, rather than looking at each item in the inventory individually.

The approach we used is to compute the partial correlation for twin similarity in the overall index for the 28 W-P items, controlling for (partialing out) the influence of the degree of parental similarity on the overall index. The implication for relative twin agreement is simple; if parental agreement results from assortative mating, then the resulting increase in genetic similarity will increase DZ twin correlations (the more alike genetically the parents are on a trait, the more alike siblings will be on a trait). Controlling for parental similarity will therefore reduce the size of the DZ twin correlations. However, parental agreement resulting from assortative mating and the resulting increase in genetic 


\begin{tabular}{|c|c|c|c|c|c|c|c|c|c|c|c|c|c|}
\hline \multirow[b]{3}{*}{ Attitude Item } & \multicolumn{6}{|c|}{ Virginia 30K Data } & \multicolumn{7}{|c|}{ Australian Data } \\
\hline & \multicolumn{3}{|c|}{$\begin{array}{l}\text { Heritability, } \\
2 *(\mathrm{MZ}-\mathrm{DZ})\end{array}$} & \multicolumn{3}{|c|}{$\begin{array}{c}\text { Shared } \\
\text { Environment, } \\
(2 * D Z)-M Z\end{array}$} & \multirow[b]{2}{*}{ Attitude Item } & \multicolumn{3}{|c|}{$\begin{array}{c}\text { Heritability } \\
2 *(M Z-D Z)\end{array}$} & \multicolumn{3}{|c|}{$\begin{array}{c}\text { Shared } \\
\text { Environment } \\
(2 * D Z)-M Z\end{array}$} \\
\hline & Male & Female & Mean & Male & Female & Mean & & Male & Female & Mean & Male & Female & Mean \\
\hline Astrology & 0.49 & 0.33 & 0.41 & -0.01 & 0.14 & 0.06 & Horoscopes & 0.30 & 0.32 & 0.31 & 0.07 & 0.18 & 0.13 \\
\hline Pacifism & 0.46 & 0.34 & 0.40 & -0.09 & -0.03 & -0.06 & Disarmament & 0.26 & .48 & 0.37 & 0.09 & -0.08 & 0.01 \\
\hline Censorship & 0.55 & 0.20 & 0.37 & -0.12 & 0.17 & 0.02 & Censorship & 0.30 & 0.48 & 0.39 & 0.11 & -0.03 & 0.04 \\
\hline Socialism & 0.33 & 0.36 & 0.35 & 0.05 & 0.08 & 0.07 & Socialism & 0.04 & 0.24 & 0.14 & 0.38 & 0.24 & 0.31 \\
\hline Militar & 0.42 & 0.24 & 0.33 & -0.02 & 0.12 & 0.05 & Military Drill & 0.32 & 0.42 & 0.37 & 0.20 & 0.08 & 0.14 \\
\hline Immigration & 0.29 & 0.35 & 0.32 & 0.16 & 0.10 & 0.13 & $\begin{array}{l}\text { Nonwhite } \\
\text { Immigration }\end{array}$ & -0.06 & 0.20 & 0.07 & 0.50 & 0.23 & 0.37 \\
\hline Death Penalty & 0.27 & 0.35 & 0.31 & 0.27 & 0.19 & 0.23 & Death Penalty & 0.42 & 0.54 & 0.48 & 0.10 & -0.03 & 0.04 \\
\hline $\begin{array}{l}\text { Women's } \\
\text { Liberation }\end{array}$ & 0.23 & 0.35 & 0.29 & 0.08 & 0.17 & 0.13 & $\begin{array}{l}\text { Working } \\
\text { Mothers }\end{array}$ & 0.22 & 0.32 & 0.27 & 0.15 & 0.16 & 0.16 \\
\hline Segregation & 0.34 & 0.23 & 0.29 & 0.04 & 0.14 & 0.09 & Apartheid & 0.44 & 0.38 & 0.41 & 0.09 & 0.08 & 0.09 \\
\hline Modern Art & 0.31 & 0.21 & 0.26 & 0.11 & 0.22 & 0.16 & Modern Art & 0.40 & 0.22 & 0.31 & -0.02 & 0.26 & 0.12 \\
\hline Abortion & 0.26 & 0.24 & 0.25 & 0.29 & 0.44 & 0.36 & $\begin{array}{l}\text { Legalised } \\
\text { Abortion }\end{array}$ & 0.10 & 0.42 & 0.26 & 0.50 & 0.25 & 0.38 \\
\hline Divorce & 0.20 & 0.28 & 0.24 & 0.22 & 0.21 & 0.21 & Divorce & 0.16 & 0.44 & 0.30 & 0.31 & 0.10 & 0.21 \\
\hline Mean & 0.35 & 0.29 & 0.32 & 0.08 & 0.16 & 0.12 & Mean & 0.24 & 0.37 & 0.31 & 0.21 & 0.12 & 0.16 \\
\hline
\end{tabular}

Source: Access to the original U.S. data provided by Eaves et al., principal investigators, Virginia $30 \mathrm{~K}$ twin study. Australian data computed from Martin et al. 1986, Table 1, p. 4365.

similarity will not increase MZ twin correlations (MZ twins are already genetically identical, regardless of parental similarity or dissimilarity). Therefore, controlling for parental similarity should have no effect on the size of the MZ twin correlations. In contrast, if parental agreement results from persuasion or from a shared environment for the couple, then the impact of parental agreement has no genetic implications and operates on their offspring solely through its influence on the offsprings' shared environment. This should produce relatively higher correlations of equal magnitude for both MZ and DZ twins and, therefore, lead to roughly comparable reductions in both the $\mathrm{MZ}$ and the $\mathrm{DZ}$ correlations when we partial out the effect of parental agreement.

The results for a partial correlation analysis controlling for parental agreement are reported in Table 2, on the row just below the results for the overall index. For MZ twins the issue of whether their parents agree or disagree on a particular item makes little difference (.65 without control versus .64 after partialing out the effect of parental agreement). In contrast, the correlation between DZ twins decreases modestly when the impact of parental agreement is removed (.43 without control versus .37 after partialing out the effect of parental agreement). Further, the tendency of assortative mating to deflate estimates of heritability while inflating estimates of the impact of shared environment is clear. Without controls, the estimate of heritability for the overall index is .43 and the average estimate of the impact of shared environment is .22. When the impact of parental agreement is partialed out, the aver- age estimate of heritability rises to .53 , and the average estimate of the impact of shared environment drops to .11. Note that the traditional socialization account of attitude formation is not at odds with this last finding. If the issue positions of parents are in conflict, then we would hardly expect this shared conflicted setting to yield sibling agreement. ${ }^{8}$

\section{COMPARATIVE POLITICAL GENETICS: EVIDENCE FROM AUSTRALIA}

Even with a data set as large as the Virginia $30 \mathrm{~K}$, questions may arise over the extent to which conclusions are bound by time and geography. As a result, it is helpful to note results from a quite different context and a slightly different time period. Table 3 presents a comparison of the key summary results in Table 1 from the Virginia 30K study to comparable results in the Australian data described before (Truett et al. 1994; see also Lake et al. 2000). While the Australian study

\footnotetext{
${ }^{8}$ The same sort of control for parental agreement that was applied to the W-P inventory was applied to the party affiliation analysis. Because this is only a single item, the results are much less reliable than those averaged across the 28 items. However, despite the fact that assortative mating clearly takes place with regard to party ID (only 24 of the 543 parent pairs had opposite party affiliations), the general pattern of party ID being due more to shared environment than to heredity holds up. Using a very broad definition of disagreement (i.e., anything short of exact agreement on a five-point scale), the shared environment estimate weakens modestly but remains high, at almost twice the heritability estimate in the subset of twin pairs with parents in some degree of disagreement on party affiliation.
} 
utilized a larger set of W-P items (50 in all, compared to 28 in the U.S. study), the items were a mix of political and social items, and only six items appeared in exactly the same form in both studies. An additional six items were similar enough, in our judgment, to merit comparison, and they are included in Table 2 with the Australian wording italicized.

The broad picture from Table 3, and its comparison to Tables 1 and 2, is one of remarkable similarity. The mean heritability for the 12 item subset of the Virginia $30 \mathrm{~K}$ data is .32 for the full 28 items in Table 1 and .31 for the 12-item subset of the Australian data. The mean estimate for the effect of shared environment for the 12 item subset of the Virginia $30 \mathrm{~K}$ data is .12 compared to .16 for the full 28 items in Table 1 and .16 for the 12-item subset of the Australian data. Thus the general pattern of a relatively greater role for heredity compared to shared environment detailed above in the discussion of the U.S. data in Tables 1 and 2 also applies to the Australian data in Table 3. While most of the individual items also have broadly comparable results in the two countries, a few, specifically "socialism" and "immigration" ("nonwhite immigration" in the Australian study), are noticeably different. In both cases the U.S. pattern of substantially higher relative heritability is reversed in the Australian data, where we see evidence of relatively higher shared environmental effects. Whether these are meaningful reflections of differences in how these items relate to deeper political orientations is not clear, but they are in any case the exceptions rather than the rule. ${ }^{9}$

\section{THE GENETICS OF POLITICAL IDEOLOGY}

The possibility that attitudes and behaviors are influenced by genetic variables is an emotionally charged topic so it is important that readers understand the claims being made. Partitioning the origins of human traits, whether they be physiological or behavioral, into the discrete, quantifiable components of genetic inheritance, shared environment, and unshared environment should not be taken to imply that these components work separately. Rather these numbers only provide a rough indication of the influence of three categories of independent variables that are intimately intertwined. (Moreover, they are estimates of the ability of independent variables to account for variance in the dependent variables not for the variables themselves.) As mentioned earlier, gene-culture interaction is the key to understanding the source of political attitudes and behaviors, just as it is the key to understanding most physical and behavioral aspects of the human condition. Genes do not work in isolation and instead generally influence the extent to which organisms are

\footnotetext{
${ }^{9}$ In this case, the different results with regard to socialism could reflect different meanings of the phrase in the two countries. In Australia, the term socialism is closer to a party identification label, whereas in the United States it has more loaded ideological connotations. Likewise, the addition of the qualifier "nonwhite" to immigration raises questions of what the key stimulus is.
}

responsive to particular environmental conditions (see Boyd and Richerson 1985 and Masters 1993).

And this conditioning influence of genetics on complex social behaviors is not the product of a single gene but rather numerous genes that, to make matters more complicated, appear to combine in configural as opposed to additive ways. The same set of multiple genes may influence behavior in different ways depending on the order in which they express themselves and the manner in which they interact with other genes. Recent discoveries also suggest that biological markers of phenotypic manifestations include the manner in which DNA is packed in the nucleus, particularly the physical location of genes relative to other genes and to the histones that help to give DNA its structure. An accurate understanding of gene expression appears to require knowledge not just of the sequence of nucleotides (e.g., ATCAGG) that constitutes the gene itself but also of the context in which each gene resides, thus forming an interesting parallel to the way we must try to understand the organisms (e.g., human beings) genes help to construct (for a good summary, see Kosack and Groudine 2004; also see Lykken 1999).

Individual genes for behaviors do not exist and no one denies that humans have the capacity to act against genetic predispositions. But predictably dissimilar correlations of social and political attitudes among people with greater and lesser shared genotypes suggest that behaviors are often shaped by forces of which the actors themselves are not consciously aware, a point that is made with some force by Bargh and Chartrand (1999), Marcus (2002), Marcus, Neuman, and MacKuen (2000), McDermott (2004), and Wegner (2002). It is not biological determinism to posit the existence of complex collections of genes that increase the probability that certain people will display heightened or deadened response patterns to given environmental cues. And it is not antibehavioralism to suggest that true explanations of the source of political attitudes and behaviors will be found when we combine our currently detailed understanding of environmental forces with a recognition that genetic variables subtly but importantly condition human responses to environmental stimuli.

\section{IMPLICATIONS FOR POLITICS}

It is important to note that none of the data or arguments presented in this paper indicates that extant empirical knowledge about political socialization is useless. In fact, it strongly reinforces many of the most salient findings in that research stream. We know from that research, for example, that if both parents share a political identification, there is a high degree of likelihood that their offspring will have that same political identification (Jennings and Niemi 1968; Tedin 1974). Our "twin study" results confirm this finding. One of the peculiar findings in the political socialization literature even makes more sense when a role for genetic inheritance in conceded. Scholars have occasionally puzzled over the fact that family arrangements and 
styles of operation have little if any impact on the extent to which there is a match between parental and offspring political attitudes on a wide variety of items (see Jennings and Niemi 1968, 180-83). Fathers do not have more influence over sons, and mothers do not have more influence over daughters; fathers are not generally more influential; the distribution of power within the family is irrelevant to parent-child correlations (i.e., neither highly autocratic, highly permissive, nor middling arrangements affect the extent to which attitudes are correlated); the degree to which children and parents feel close to each other does not matter; the frequency with which the family discusses politics does not much affect correspondence between offspring and parent views (though, as we would have predicted since it is based on active socialization, party identification is more sensitive to family arrangements); and the extent to which politics is important to the parents is also irrelevant. Scholars grounded in traditional behavioralism have difficulty accounting for these "perplexing configurations" (Jennings and Niemi 1968, 183), but recognizing that the correlations between the views of parents and children derive more from genetics than familial socialization makes it much less surprising that the strength of these correlations is not reliant on family arrangements (for an example of political science work that does posit a role for genetics, see Peterson 1983).

Still, the substantive findings we present here offer a direct challenge to common assumptions and interpretations that political attitudes and behavioral tendencies are shaped primarily or even exclusively by environmental, especially familial, factors. Setting aside the important special case of party identification, we find that political attitudes are influenced much more heavily by genetics than by parental socialization. For the overall index of political conservatism, genetics accounts for approximately half of the variance in ideology, while shared environment including parental influence accounts for only $11 \%$. And in the case of the variance in people's tendencies to possess political opinions at all, regardless of their ideological direction, genetics explains one-third of the variance, and shared environment is completely inconsequential.

What are the implications of these findings for political science? Acknowledging a role for heritability in politics affects our understanding of, first, political issues, second, political learning, and, third, political cleavages. Inherited attitudes seem to be demonstrably different than acquired attitudes. Tesser (1993) provides evidence that attitudes higher in heritability are manifested more quickly, are more resistant to change, and increase the likelihood that people will be attracted to those who share those particular attitudes. It has long been known that certain political issues seem "hard" to people, and others seem "easy," presumably because some issues trigger "gut responses" while others do not (Carmines and Stimson 1980,79), but no explanation has yet been offered for why given issues do or do not elicit gut responses. Why do social, more than economic, issues tend to hit people in the gut, even though both constitute ongoing and equally complex societal concerns? In light of the new findings, one distinct possibility is that easy "gut" issues tend to be those that are more heritable.

To the extent that political ideologies are inherited and not learned, they become more difficult to manipulate. Conservative parents who try to make their children conservative by carefully controlling their children's environments are probably overestimating the importance of those environments. Offspring of such parents are likely to end up being conservative but less because of the environment created by the parents than the genes passed along by the parents. A political match between parents and children should not be taken to be the result of a socialization process-that is, the active postnatal transmission of views-just as political mismatches between parent and child should not be taken as evidence against a role for genetics. Parent-child mismatches are distinctly possible given the uncertainties of meiosis (the random selection of just $50 \%$ of each parent's DNA) and the possibility for occasional errors in the transcription and translation of genes (mutations). These mismatches are likely to be the primary cause of the fact that some children rebel against the views of their parents but most do not-a pattern that environmental factors have never explained satisfactorily.

Finally, we go into somewhat greater detail to illustrate the manner in which results such as ours can be of use in understanding the divisions characterizing virtually all polities and, certainly, the United States in the early twenty-first century. Remember, genes influence people's outlooks and personalities, and it is these broad features that then predispose individuals toward suites of specific attitudes. This interpretation likely explains the otherwise puzzling consistency in ideological divisions that is present across space and time. The package of attitudes held, for example, by conservatives in the modern United States is remarkably similar to that held by conservatives in other cultures and at earlier times in American history (on the durability of the liberal-conservative spectrum in the United States, see Poole and Rosenthal 1997). Environmental determinists have no convincing explanation for the pervasiveness of this division but genetics does.

If, as our results suggest, there is a genetic basis for the varying political views people hold, and if, as seems probable, genetic transmission frequently affects clusters of political attitudes, we are likely to observe broad but distinct political phenotypes. The number of these phenotypes may vary, but for purposes of illustration we discuss two probable orientations. One is characterized by a relatively strong suspicion of out-groups (e.g., immigrants), a yearning for in-group unity and strong leadership, especially if there is an out-group threat ("Do not question the President while we are at war with terrorists"), a desire for clear, unbending moral and behavioral codes (strict constructionists), a fondness for swift and severe punishment for violations of this code (the death penalty), a fondness for systematization (procedural due process), a willingness to tolerate inequality (opposition to redistributive policies), 
and an inherently pessimistic view of human nature (life is "nasty, brutish, and short").

The other phenotype is characterized by relatively tolerant attitudes toward out-groups, a desire to take a more context-dependent rather than rule-based approach to proper behavior (substantive due process), an inherently optimistic view of human nature (people should be given the benefit of the doubt), a distaste for preset punishments (mitigating circumstances), a preference for group togetherness but not necessarily unity ("We can all get along even though we are quite different"), suspicion of hierarchy, certainty, and strong leadership (flip-flopping is not a character flaw), an aversion to inequality (e.g., support for a graduated income tax), and greater general empathic tendencies (rehabilitate, don't punish).

Common political usage would call the first phenotype conservative and the second liberal, but we seek phrases that are less connected to political ideologies and that indicate that these two phenotypes run to the very orientation of people to society, leadership, knowledge, group life, and the human condition. Thus, we label the first "absolutist" and the second "contextualist." This fundamental dimension offers a credible precursor to basic cleavages manifested in a broad range of human social activity: politics (conservatives/liberals), religion (fundamentalists/secular humanists), law (procedural/substantive due process), education (phonics/ whole language), art (traditional form-based realism/modern free-form impressionism), sports (football/frisbee), medicine (traditional AMA/wholistic), morality (enduring standards/situational ethics), and scientific inquiry (formal/empirical). In our view, all of these vexing perennial dichotomies are related cultural expressions of a deep-seated genetic divide in human behavioral predispositions and capabilities. We certainly are not asserting that everyone holds one of these two orientations. Even if the individual genes involved with absolutism or contextualism tend to move together, this does not mean they always do. Some individuals may carry, say, an absolutist's aversion to out-groups but a contextualist's rejection of a universalistic behavioral code. Moreover, genes not included in these central packages, perhaps those related to extroversion, ambition, and intelligence, often muddy the waters.

More importantly, let us not forget that a heritable component of $50 \%$ for political ideology and probably somewhat higher for the absolutist-contextualist dimension still leaves plenty of opportunity for the environment to alter attitudes and behaviors - and even orientation. An individual with a contextualist genotype who has been repeatedly victimized by out-group members, or who has simply spent a great deal of time listening to persuasive absolutists, may adopt attitudes that run against type. Thus, even if a political system started with two pure genotypes, it would soon display a fascinating array of expressed orientations and beliefs, intensity levels, and degrees of involvement even as the system would continue to revolve around the central division between absolutists and contextualists.
Such an account is speculative at this point but is fully consistent with the findings presented here, with previous research on the durability of political ideologies, and with recent events in the United States. Accounts of the 2004 election, for example, that do not invoke this fundamental difference in orientation have fallen flat. Issues did not determine vote choice for the many citizens who expressed disagreement with existing economic policies and/or the war in Iraq yet still voted for the incumbent president, George W. Bush. Indeed, if the focus remains on issues, the resultant description of the American public is grossly at odds with reality. Morris Fiorina's (2005) creative analysis of survey responses indicates that Americans can be placed in the middle on many important issues, but if this is true, then what explains the vitriol and intensity of feeling displayed by so many ordinary Americans in 2004 ?

Issues do not explain Americans' politics. Many Americans admit that they do not follow or understand the issues (Hibbing and Theiss-Morse 2002), and to the extent they do, they support whatever their preferred politician and party seems to support (Page and Jones 1979). In the 1990s, a Democratic president (Bill Clinton) transformed welfare to workfare; then in the 2000s, his Republican successor (George W. Bush) greatly expanded federal involvement in both education and the provision of prescription drugs for senior citizens. If the enactors of these policies were reversed, the groups of citizens displaying support for the policies also would have reversed. Similarly, if a Republican president had committed adultery with a young intern or if a Democratic president had dramatically worsened the deficit and taken the country to war in a far-off land on the basis of undeniably incorrect beliefs about the opponents' nuclear and chemical weapons capabilities, the positions of most voters on the acceptability of these conditions would be completely reversed. Issue positions generally reflect divisions; they do not create them.

Instead, the most accurate account of voting behavior in 2004 moves beyond issues to the basic, partially genotypic orientations described above. This sort of broad orientation is not far removed from what most commentators are trying to capture by reference to a "moral" division in the electorate, but without tying it to specific moral issues such as gay rights. The chasm inspiring so much hostility between citizens of the United States in the early twenty-first century did not divide supporters and opponents of privatizing Social Security; it did not even divide supporters and opponents of gun control. Rather, as has typically been the case, it divided absolutists and contextualists.

And the prospects for eliminating this divide are not promising. Since mate choice appears to be heavily tilted toward those with similar social and political attitudes, no genetic melting pot exists for these traits. Thus, the evidence presented here on assortative mating should be quite sobering to those in search of unity and togetherness. If anything, the heritability of orientation in combination with assortative mating may exacerbate the current divide. 
But admitting that genetics influences political attitudes could actually help to mute societal divisions. Currently, absolutists and contextualists simply do not connect, and the result is frustration. To contextualists, absolutists appear simplistic and selfish; to absolutists, contextualists appear naive and indecisive. Each side talks past, and is authentically miffed by, the other. Recognizing that our political antagonists probably have a different genetic predisposition to people, life, human nature, and politics may serve to ease frustrations and, eventually, to improve communications across the chasm. If absolutists spent more time trying to think like contextualists and contextualists trying to think like absolutists, understanding would be increased and debates could become more constructive. As frustrating as it may be to debate with someone who holds such different orientations, value exists in recognizing that intransigence is not the result of willful bullheadedness but, rather, genetically driven differences in orientation.

The exciting next step is to understand the reason such distinct orientations have evolved and lasted. Evolutionary psychologists tend to assume that all enduring traits are adaptive (for a dissenting view, see Gould 2000) since natural selection drives out variation and makes adaptive traits ever more common. In this organism-based interpretation, whichever orientation - absolutism or contextualism-is evolutionarily superior should soon come to numerically dominate the other. This is possible but unlikely. An alternative group-based interpretation sees variation itself as adaptive (see Alford and Hibbing 2004 and Sober and Wilson 1998). The benefits of genetic variation are most easily observed in the ability of differential immune systems to prevent a group of organisms from being completely wiped out by a single pathogen, but it is easy to imagine how sociopolitical variation could also create more viable groups. In fact, computer simulations give support to the hypothesis that divergent individual-level social behaviors, such as cooperation and defection, are beneficial at the group level (Hammond 2000). As loathe as contextualists and absolutists are to admit it, the presence of the other orientation may make a society stronger.

\section{REFERENCES}

Adorno, Theodore W., Else Frenkel-Brunswik, Daniel Levinson, and R. N. Sanford. 1950. The Authoritarian Personality. New York: Harper.

Alford, John R., and John R. Hibbing. 2004. "The Origin of Politics: An Evolutionary Theory of Political Behavior." Perspectives on Politics 2 (December): 707-23.

Bargh, J. A., and T. L. Chartrand. 1999. "The Unbearable Automaticity of Being." American Psychologist 54 (July): 462-79.

Bouchard, T. J., Jr. 1998. "Genetic and Environmental Influences on Intelligence and Special Mental Abilities." Human Biology 70 (2): 257-59.

Bouchard, T. J., Jr., and J. C. Loehlin. 2001. "Genes, Personality, and Evolution.” Behavior Genetics 31 (January): 23-73.

Bouchard, T. J., Jr., and Matt McGue. 2003. "Genetic and Environmental Influences on Human Psychological Differences.” Journal of Neurobiology 54 (1): 4-45.
Bouchard, T. J., Jr., D. T. Lykken, M. McGue, N. L. Segal, and A. Tellegen. 1990. "Sources of Human Psychological Differences: The Minnesota Study of Twins Reared Apart." Science 12 (October): $223-28$

Bouchard, T. J., Jr., Matt McGue, D. T. Lykken, and A. Tellegen. 1999. "Intrinsic and Extrinsic Religiousness." Twin Research 2 (June): 88-98.

Boyd, Robert, and Peter J. Richerson. 1985. Culture and the Evolutionary Process. Chicago: University of Chicago Press.

Breland, Keller, and Marian Breland. 1961. "The Misbehavior of Organisms." American Psychologist 16 (9): 681-84.

Brewer, Marilyn B. 2000. "Superordinate Goals Vs. Superordinate Identity as Bases of Cooperation.” In Social Identity Processes, ed. Dora Capozza and Rupert Brown. London: Sage.

Campbell, Angus, Philip E. Converse, Warren E. Miller, and Donald E. Stokes. 1960. The American Voter. New York: John Wiley.

Carmines, Edward G., and James A. Stimson. 1980. "The Two Faces of Issue Voting." American Political Science Review 74 (March): 78-91.

Caspi, Avshalom, Karen Sugden, Terrie E. Moffitt, Alan Taylor, Ian W. Craig, Honalee Harrington, Joseph McClay, Jonathan Mill, Judy Martin, Antony Braithwaite, and Richie Poulton. 2003. "Influence of Life Stress on Depression: Moderation by a Polymorphism in the 5-HTT Gene." Science 18 (July): 386-89.

Converse, Philip E. 1964. "The Nature of Belief Systems in Mass Publics." In Ideology and Discontent, ed. David Apter. New York: Free Press.

Cook, Timothy E. 1985. "The Bear Market in Political Socialization and the Costs of Misunderstood Psychological Theories." American Political Science Review 79 (December): 1079-93.

Crelia, R. A., and A. Tesser. 1996. "Attitude Heritability and Attitude Reinforcement." Personality and Individual Differences 21 (November): 803-8.

Easton, David, and Jack Dennis. 1969. Children in the Political System. New York: McGraw-Hill.

Eaves, L. J., H. J. Eysenck, and N. G. Martin. 1989. Genes, Culture, and Personality: An Empirical Approach. San Diego: Academic Press.

Eaves, L. J., N. G. Martin, and A. C. Heath. 1990. "Religious Affiliation in Twins and Their Parents." Behavior Genetics 20 (January): $1-22$.

Eysenck, H. J. 1954. The Psychology of Politics. London: Routledge. Fiorina, Morris P. 1981. Retrospective Voting in American National Elections. New Haven, CT: Yale University Press.

Fiorina, Morris P. 2005. Culture War? The Myth of a Polarized America. New York: Pearson Longman.

Gould, Stephen Jay. 2000. "More Things in Heaven and Earth.” In Alas, Poor Darwin, ed. Hillary Rose and Steven Rose. New York: Harmony Books.

Greenstein, Fred I. 1960. "The Benevolent Leader: Children's Images of Political Authority.” American Political Science Review 54 (December): 934-43.

Hammond, Ross. 2000. "Endogenous Transition Dynamics in Corruption: An Agent-Based Computer Model.” Brookings Institution. Typescript.

Hibbing, John R., and John R. Alford. 2004. "Accepting Authoritative Decisions: Humans as Wary Cooperators." American Journal of Political Science 48 (January): 62-76.

Hibbing, John R., and Elizabeth Theiss-Morse. 2002. Stealth Democracy: Americans' Beliefs about How Government Should Work. New York: Cambridge University Press.

Jennings, M. Kent., and Richard G. Niemi. 1968. "The Transmission of Political Values from Parent to Child." American Political Science Review 62 (March): 169-83.

Jennings, M. Kent, and Richard G. Niemi. 1991. "Issues and Inheritance in the Formation of Party Identification." American Journal of Political Science 35 (November): 970-88.

Kosack, Steven T., and Mark Groudine. 2004. "Gene Order and Dynamic Domains." Science 22 (October): 644-47.

Lake, Robert I. E., Lindon J. Eaves, Hermine H. M. Maes, Andrew C. Heath, and Nicholas G. Martin. 2000. "Further Evidence Against the Environmental Transmission of Individual Differences in Neuroticism from a Collaborative Study of 45,850 Twins and Relatives on Two Continents." Behavior Genetics 30 (May): 223-33.

Laswell, Harold. 1930. Psychopathology and Politics. Chicago: University of Chicago Press. 
Lodge, Milton, Kathleen McGraw, and Pat Stroh. 1989. “An Impression-Driven Model of Candidate Formation." American Political Science Review 83 (June): 399-420.

Lykken, D. T. 1998. "The Genetics of Genius." In Genius and the Mind: Studies of Creativity and Temperament in the Historical Record, ed. A. Steptoe. Oxford: Oxford University Press.

Lykken, David T. 1999. Happiness: What Studies on Twins Show Us about Nature, Nurture, and the Happiness Set Point. New York: Golden Books.

Maes, H. H., M. C. Neale, N. G. Martin, A. C. Heath, and L. J. Eaves. 1999. "Religious Attendance and Frequency of Alcohol Use." Twin Research 2 (June): 169-79.

Marcus, Gary. 2004. The Birth of the Mind. New York: Basic Books.

Marcus, George E. 2002. The Sentimental Citizen: Emotion in Democratic Politics. University Park, PA: Penn State University Press.

Marcus, George E., John L. Sullivan, Elizabeth Theiss-Morse, and Sandra L. Wood. 1995. With Malice Toward Some. New York: Cambridge University Press.

Marcus, George E., W. Russell Neuman, and Michael MacKuen. 2000. Affective Intelligence and Political Judgment. Chicago: University of Chicago Press.

Martin, N. G., L. J. Eaves, A. C. Heath, R. Jardine, L. M. Feingold, and H. J. Eysenck. 1986. "Transmission of Social Attitudes." Proceedings of the National Academy of Sciences 15 (June): 4364-68.

Masters, Roger D. 1993. Beyond Relativism: Science and Human Values. Hanover, NH: University Press of New England.

McCloskey, Herbert. 1958. "Conservatism and Personality." American Political Science Review 52 (March): 27-45.

McDermott, Rose. 2004. "The Feeling of Rationality: The Meaning of Neuroscientific Advances for Political Science." Perspectives on Politics 2 (December): 691-707.

Merelman, Richard M. 1986. "Revitalizing Political Socialization." In Political Psychology, San Francisco: Jossey-Bass. ed. Richard Herrmann.

Monroe, Kristen Renwick. 2004. The Hand of Compassion. Princeton, NJ: Princeton University Press.

Orbell, John, Tomonori Morikawa, Jason Hartwig, James Hanley, and Nicholas Allen. 2004. "Machiavellian Intelligence as a Basis for the Evolution of Cooperative Dispositions." American Political Science Review 98 (March): 1-17.

Page, Benjamin L., and Calvin Jones. 1979. "Reciprocal Effects of Policy Preferences, Party Loyalties, and the Vote." American Political Science Review 73 (December): 1071-89.

Peterson, Steven A. 1983. "Biology and Political Socialization: A Cognitive Developmental Link?" Political Psychology 4 (2): 26588.

Plomin, R. 1990. "The Role of Inheritance in Behavior." Science 13 (April): 183-248.

Plomin, R., D. W. Fulker, R. Corley, and J. C. DeFries. 1997. "Nature, Nurture, and Cognitive Development from 1 to 16 years: A ParentOffspring Adoption Study." Psychological Science 8 (November): 442-47.

Plomin, R., R. Corley, A. Caspi, D. W. Fulker, and J. DeFries. 1998. "Adoption Results for Self-Reported Personality: Evidence for Nonadditive Genetic Effects?" Journal of Personality and Social Psychology 75 (July): 211-18.

Plomin, R., J. C. DeFries, G. E. McClearn, and P. McGuffin. 2001. Behavioral Genetics. 4th ed. New York: Worth.
Poole, Keith, and Howard Rosenthal. 1997. Congress: A PoliticalEconomic History of Roll Call Voting. New York: Oxford University Press.

Prescott, Carol A., Ronald C. Johnson, and John J. McArdle. 1999. "Chorion Type as a Possible Influence on the Results and Interpretation of Twin Study Data." Twin Research 2 (December): 244 49.

Rhee, S. H., and I. D. Waldman. 2002. "Genetic and Environmental Influences on Antisocial Behavior: A Meta-analysis of Twin and Adoption Studies." Psychological Bulletin 128 (May): 490-529.

Ridley, Matt. 2003. Nature Via Nurture. New York: Harper Collins.

Rushton, J. Philipe, Christine H. Littlefield, and Charles J. Lumsden. 1986. "Gene-Culture Coevolution of Complex Social Behavior: Human Altruism and Mate Choice." Proceedings of the National Academy of Sciences 1 (October): 7340-43.

Sacerdote, Bruce. 2004. "What Happens When We Randomly Assign Children to Families?" National Bureau of Economic Research Working Paper. Typescript.

Scarr S., and R. Weinberg. 1981. "The Transmission of Authoritarianism in Families: Genetic Resemblance in Social-political Attitudes." In Race, Social Class, and Individual Differences, ed. S. Scarr. Hillsdale, NJ: Erlbaum.

Searing, Donald, D. J. J. Schwartz, and A. E. Lind. 1973. "The Structuring Principle: Political Socialization and Belief Systems." American Political Science Review 67 (June): 415-32.

Sears, David O. 1989. "Whither Political Socialization Research? The Question of Persistence." In Political Socialization, Citizenship Education, and Democracy, ed. O. Ichilov. New York: Teachers College Press.

Sober, Elliott, and David Sloan Wilson. 1998. Unto Others: The Evolution and Psychology of Unselfish Behavior. Cambridge, MA: Harvard University Press.

Stouffer, S. 1955. Communism, Conformity, and Civil Liberties. New York: Doubleday.

Tedin, Kent L. 1974. "The Influence of Parents on the Political Attitudes of Adolescents." American Political Science Review 68 (November): 1579-92.

Tesser, A. 1993. "The Importance of Heritability in Psychological Research: The Case of Attitudes." Psychological Review 100 (January): 129-42.

Truett, K. R., L. J. Eaves, E. E. Walters, A. C. Heath, J. K. Hewitt, J. M. Meyer, J. Silberg, M. C. Neale, N. G. Martin, and K. S. Kendler. 1994. "A Model for Analysis of Family Resemblance in Extended Kinships of Twins. Behavior Genetics 24 (January): $35-49$.

Wegner, Daniel M. 2002. The Illusion of Conscious Will. Cambridge, MA: MIT Press.

Wiggins, J., and P. Trapnell. 1997. "Personality Structure: The Return of the Big Five.” In R. Hogan, J. Johnson, and S. Biggs, ed. Handbook of Personality Psychology. San Diego: Academic Press.

Zaller, John R. 1992. The Nature and Origins of Mass Opinion. New York: Cambridge University Press.

Zhang, Xiaodong, Paul R. Gainetdinov, Jean-Martin Beaulieu, Tatyana D. Sotnikova, Lauranell H. Burch, Redford B. Williams, David A. Schwartz, K. Ranga, R. Krishnan, and Marc G. Caron. 2005. "Loss of Function Mutation in Tryptophan Hydroxlylase-2 Identified in Unipolar Major Depression." Neuron 6 (January): $11-16$. 